\title{
THE PERPETUATION OF IDENTITY AND SYMBOLIC RESISTANCE OF HIZBUT TAHRIR INDONESIA AFTER THE OFFICIAL DISBANDMENT IN 2017
}

\author{
Inayah Rohmaniyah \\ Universitas Islam Negeri Sunan Kalijaga Yogyakarta, Indonesia \\ E-mail: rochmaniyah@yahoo.com
}

\begin{abstract}
The Government of Indonesia has legally revoked the legal status of the Hizbut Tahrir Indonesia (HTI) organization, yet thousands of HTI members have embraced strong group identities and systematic resistance strategies. This article reveals the effectiveness of the Government's efforts and their impact on the sustainability or discontinuity of the HTI movement. Based on qualitative data extracted from field research in Gorontalo in 2018 and the theory of identity and resistance, this article reveals the collective identity of the HTI group, models of resistance, and change of space and strategy the members made after the disbandment of the organization. The official revocation has encouraged activists to take symbolic resistance through limited religious circles on campus and in villages, the use of various socio-religious activities in the community, and a door-to-door visit. The dominant narrative of the true meaning of Islam and the discipline of the five daily prayers has made this organization remains accepted in society even though it has been formally disbanded. The pattern of perpetuating ideology, narrative and organizational idealism is carried out through integrating or transforming other organizations; returning to the previous organization which is theologically not in conflict with HTI; applying HTI thoughts and ideology in the organizations they join currently; or leaving out formally from the HTI organization and operate HTI thoughts and ideology in individual life.
\end{abstract}

Keywords: Identity; depersonalization; strategy; symbolic resistance; perpetuation. 


\section{Introduction}

The political power of the Indonesian Government has formally succeeded in disbanding the organization of Hizbut Tahrir Indonesia (HTI). Yet, the impact of the Government's efforts on HTI members' loyalty and the perpetuation of their ideology and movement, along with its thousand members ${ }^{1}$ and strong collective identity as well, remains questionable. The government has revoked the legal status of the HTI organization on July $19^{\text {th }}, 2017$ as it was deemed to deviate from Pancasila and National Unity of the Republic of Indonesia (NKRI) ideology. ${ }^{2}$ Indeed, it has allegedly emerged as a key force against the National Ideology, which is believed to be non-Islamic. HTI's activities and propagation are weighed as causing conflict in society and threatening the life of the nation. Besides, the movement's tricky strategy in using sensitive issues and mass mobilization against the Government made this movement considered politically dangerous. ${ }^{3}$ HTI members were even reported to have succeeded in changing the face of Indonesian Islam to become intolerant, exclusive, and embracing hatred. ${ }^{4}$ The article inquires whether the power of the Government that successfully dominates public discourse on the danger of HTI and the urgency of disbanding this organization can weaken the identity of the group and terminate its members' resistance.

HTI grows to be a substantial challenge for the Indonesian government and mainstream society that has made persistent efforts to uphold and safeguard the political idealism of the Nation-State of the Republic of Indonesia and the State ideology of Pancasila. It is also in opposition to the state's interest in

\footnotetext{
${ }^{1}$ Editorial, "Tanggapi Data Mahfud MD di ILC, Mantan HTI Jelaskan Jumlah Anggota HTI Hanya Segini," Duta Islam, available at https://www. dutaislam.com/2018/06/tanggapi-data-mahfud-md-di-ilc-mantan-hti-jelaskanjumlah-anggota-hti-hanya-segini.html accessed on June 08, 2018.

2 "Kemenkumham: Pembubaran HTI Berdasarkan Data dan Fakta," available at https://nasional.kompas.com/read/2017/07/19/10553011/kemenkumham-pembubaran-hti-berdasarkan-data-dan-fakta?page $=$ all accessed on October 21, 2017.

3 Markas Besar Tentara Nasional Indonesia Pusat Pengkajian Strategis, Menghidupkan Kembali Kekhalifahan di Nusantara: Hiøbut Tabrir Indonesia (HTI), Strategi Mobilisasi dan dampaknya Bagi Indonesia (Jakarta: Mabes TNI, 2010) 53.

4 Abdurrahman Wahid, "Musuh dalam Selimut," in Ilusi Negara Islam Ekspansi Gerakan Islam Transnasional di Indonesia (Jakarta: The Wahid Institute, 2009), 20.
} 
mainstreaming the moderation of Islam within both political and Muslim social life. Pancasila as State ideology requires the ideal norms of moderation of Islam, and of other religions, which is based on the spirit of respect for plurality, inclusiveness, and multicultural realities in the life of society, nation, state, and religion. However, on the one hand, the principles and values embedded in Pancasila at the practical level give the possibility for a variety of interpretations as reflected in the HTI members' distinctive interpretation. On the other hand, the interpretation of Islam as theological and ideological norms, as well as the spirit of practices and social movement in Indonesian history, has never been monolithic but multi-faces. The fact shows that Indonesia remains a country with the largest Muslim population in the world, as reported by Nurcholish Madjid (1996), but the least Arabized country and the farthest from the holy land. ${ }^{5}$

The debate over the ideal relation between Islam and the State that was historically resolved by the founders of the nation with the acceptance of Pancasila has led most Indonesians to believe that the face of peaceful Indonesian Islam will always dominate the archipelago. However, the reported spread of religion-based-social movements more particularly those considered radical and promote an exclusive understanding of religious norms and violence in the name of religion challenge the promoters of peaceful religious life and pluralism. The birth of the reform era following the collapse of the New Order in 1998 has led to the growth of democratization in the country and provided space and more freedom for all individuals and organizations. Reformation brought about fresh air in the public arena for religion-based organizations that were banned during the New Order era. Postreformation has even become fertile ground for the growth of radical Islamic groups. ${ }^{6}$ This period was marked by, among other things, the emergence of groups that emphasized criticism of what they considered the failure of modernization and offered solutions

\footnotetext{
${ }^{5}$ Nurcholish Madjid, "In Search of Islamic Roots for Modern Pluralism: The Indonesian Experiences," in Mark Woodward (ed.), Toward a New Paradigm; Recent Developments in Indonesian Islamic Thoughts (Temple, Arizona: Arizona State University, 1996), 91.

6 Wahid Foundation, "Akar Sejarah Gerakan Radikalisme di Indonesia," available at http://wahidfoundation.org/index.php/news/detail/Akar-SejarahGerakan-Radikalisme-di-Indonesia accessed on May 22, 2020.
} 
and world-views based on their exclusive Islamic interpretation, epistemology, and new political formation (Islamic state). HTI is among these groups.

Studies on the phenomena of radical-exclusive movements, including HTI, so far focused on the historical aspect of the emergence of both local and transnational radical movements. ${ }^{7}$ The second concern has been on the sociological and political aspects that encourage the formation of radical movements, especially those associated with the 1987 reform era. ${ }^{8}$ Apart from these aspects, several studies have looked at the involvement of women in these organizations. ${ }^{9}$ None of these published articles reveal the existence of Hizbut Tahrir Indonesia after the formal disbandment of the organization in 2017. This paper shows how HTI members exercise their resistance and strategic efforts, make relevant changes, and perpetuate their collective identity and ideology.

The significance of this article lies in its focus on HTI and its future as a previously phenomenal and publicly provocative organization. It has been well-known for its members' continuous movements in both grass root and elite levels and activities in the public sphere to consistently call for the establishment of the Islamic state. At the same time, they criticize openly government

\footnotetext{
${ }^{7}$ See for example Ahmad Rizky Mardhatillah Umar, "Melacak Akar Radikalisme Islam di Indonesia," Jurnal Ilmu Sosial dan Ilmu Politik, Vol. 14, No. 2 (2010); Anzar Abdullah, "Gerakan Radikalisme dalam Islam: Perspektif Historis," ADDIN: Media Dialektika Ilmu Islam, Vol. 10, No. 1 (2016); Ahmad Asrori, "Radikalisme di Indonesia: Antara Historisitas dan Antropisitas," KALAM, Vol. 9, No. 2 (2015).

8 Muzayyin Ahyar, "Membaca Gerakan Islam Radikal dan Deradikalisasi Gerakan Islam," Walisongo: Jurnal Penelitian Sosial Keagamaan, Vol 23, No. 1 (2015); Masdar Hilmy, "Radikalisme Agama dan Politik Demokrasi di Indonesia Pasca-Orde Baru," MIQOT: Jurnal Ilmu-Ilmu Keislaman, Vol. 39, No. 2 (2015); Nurjannah, "Faktor Pemicu Munculnya Radikalisme Islam Atas Nama Dakwah," Jurnal Dakwah: Media Komunikasi dan Dakwah, Vol. 14, No. 2 (2013); Asrori, "Radikalisme di Indoensia"; GP Mulyono and GP Mulyoto, "Radikalisme Agama di Indoensia (Ditinjau dari Sudut Pandang Sosiologi Kenegaraan)," Citizenship: Jurnal Pancasila dan Kewarganegaraan, Vol. 5, No. 1 (2017).

9 Zusiana Elly Triantini and Masnun Tahir, "Terpasung tak Terasa (Melihat Eksistensi Politik Perempuan HTI),” UNISIA, Vol. 32, No. 71 (2009); Wahid Foundation, "A Measure of The Extent of Socio-religious Intolerance and Radicalism within Muslim Society in Indonesia," National Survey Report, 2016.
} 
policies at the regional, national, and international levels. Contesting to win the sympathy of the Muslim community HTI use jargons that touch the sensitive side of religion to struggle in the name of upholding the truth of Islam and defend it. The article reveals how the members of this organization respond to government policy that obliterated HTI: how to perpetuate their collective identity and movement, and what strategy they follow to uphold their political ideology to establish an Islamic State in Indonesia after the disbandment. The strategy will also uncover the reasons they continuously receive support from society at the grass-roots level. By looking at the collective identity, group categorization and the strategy of the members, especially HTI in Gorontalo, the article will show the effectiveness of identity preservation and the strategy of resistance that has been undertaken.

Data in this paper is based on the results of field research conducted qualitatively in Gorontalo in 2018. Primary data contains the results of in-depth interviews with HTI female and male activists, both those who were still actively carrying out da'wah and who have formally declared themselves out from the organization following the formal banning. In addition to interviews, Focused Group Discussion with activists and former activists and HTI members both men and women were conducted to broaden and deepen the information. Focused group discussions with researchers on HTI and observers were also carried out to get a more comprehensive picture, particularly on the history, the existence, and the patterns of HTI da'wab in the local area. The data analysis follows Peter Burke's identity theory and resistance theory from James C. Scott.

Identity refers to a set of meanings or characteristics that define a person when taking a certain role as a member of a certain society or group. ${ }^{10}$ Identity becomes a control system that regulates and shapes individual perceptions and meanings to be aligned with the group. Self-identity is formed from a combination of external and internal aspects of the individual. The dynamization of someone's identity will occur when the external and internal

\footnotetext{
${ }^{10}$ Peter J. Burke and Jan E. Stets, Identity Theory (New York: Oxford University Press, 2009), 3.
} 
conditions combine. ${ }^{11}$ Self-identity provides an understanding of self-attributions owned individually and not communally. Meanwhile, social identity describes a group by identifying commonality and referring to categories of other social groups. ${ }^{12}$ When an individual sees himself as the epitome of the prototype of a group and puts aside his or her distinctive individual characteristics, this is called the depersonalization process. When depersonalization occurs, a homogeneity of perception and thought emerges. ${ }^{13}$

In addition to the aspect of social identity, James Scott portrays the dynamics of the relationship between subordinate and powerless class and the dominant ruling class and calls that the art of political disguise. ${ }^{14}$ According to him, resistance is all forms of action from subordinate groups who do not have power against the superdominant group to reducing or rejecting the claims of the dominant and powerful superdominant groups. Resistance does not have to be expressed in the form of demonstrations, revolutions, wars, or any other organized collective actions. Resistance may take a more diverse and even an individual form (hidden transcript) including ignorance, disloyalty, passivity, and other relevant forms. ${ }^{15}$ According to Scott, resistance can take two forms: open resistance or public transcript and closed resistance or hidden transcript.

The hidden transcript is theoretically defined as forms of discourse in the form of speech, behaviour, and actions of subordinated groups that are not manifested in public expression (not open to other people, or what is called public transcript) as a response to the hegemony or power exercise of stronger and dominant ruling parties. Domination practices create a hidden transcript as Scott highlights that "relations of domination are at the same time relations of resistance (resistance)." The individual may express hidden transcripts in various forms including

11 Guillermina Jasso, Identity, Social Identity, Comparison, and Status: Four Theories with a Common Core (New York: New York University, 2002), 3-4.

${ }^{12}$ Richard Jenkins, Social Identities (London: Routledge, 2004), 85-87.

${ }^{13}$ Burke and Stets, Identity Theory, 118-119.

14 James C. Scott, Domination and the Arts of Resistence: Hidden Transcipt (New Haven \& London: Yale University Press, 1990), 136.

15 James C. Scott, Weapons of the Weak: Everyday Forms of Peasant Resistance (New Haven: Yale University, 1985), 75. 
gossiping about the ruler or dominant group, instead of direct or frontal resistance. This article will look at the symbolic resistance waged by HTI groups, especially when dealing with government powers that dissolved this group.

\section{Brief History and Struggle for the Establishment of Khiläfah Islämìyah}

The organization of Hizbut Tahrir (HT) was originally founded in 1953 in Palestine by Shaykh Taqiy al-Dīn al-Nabhānī along with the rise of the idea of Islamic revivalism in the Arab world. ${ }^{16}$ The founder was the grandson of Shaykh Yüsuf alNabhānī, a well-known scholar during the Ottoman Caliphate. ${ }^{17}$ The HT movement emerged as a response to the existing movements including Islamic, nationalism, patriotism, social community and communism movements, and other moral-based movements that have sprung up in Muslim countries. ${ }^{18}$ HT members shared the idea that the existing movements were inherently manipulated by the colonialists who intended primarily to divert the attention of the Islamic community from their respective efforts to establish an Islamic caliphate. HT was established as a political party with Islam as the basis of its ideology, aiming at restoring the caliphate, regaining the unity and awakening of the Islamic world, and calling for Muslim's freedom from colonialism. The colonialization according to HT followers took its form in the hegemony of thought, system, and laws. ${ }^{19}$

Al-Nabhāni designated radical ideological politics to create an Islamic political change. Establishing Hizbut Tahrir as an Islamic political movement, he adopted the revolutionary pattern of the Islamic movement and war against ideas that were deemed

\footnotetext{
16 Lies Marcoes et al., Kesaksian Para Pengabdi: Kajian tentang Perempuan dan Fundamentalisme di Indonesia Jakarta: Rumah Kitab in cooperation with Norwegian Centre for Human Rights, 2014), 15.

17 Nidia Zuraya, "Syekh Taqiyuddin al-Nabhani: Sang Pendidi Hizbut Tahrir," Republika, published on November 18, 2018 at republika.co.id.

18 Kurniawan Abdullah, "Hizbut Tahrir Indonesia (Gerakan Politik Islam Ekstra-Parlementer)," in Imam Tholkhah and Neng Dara Afifah, Gerakan Keislaman Pasca-Orde Baru, Upaya Merambah Dimensi Baru Islam (Jakarta: Balitbang \& Diklat Keagamaan Depag, 2005), 103.

19 Markas Besar Tentara Nasional Indonesia Pusat Pengkajian Strategis, Menghidupkan Kembali, 7-8.
} 
incompatible. HTI members rejected democracy for several reasons ${ }^{20}$ more particularly for its nature of humanly system, which was considered in contradiction with the caliphate system that was based on the revelations of Allah. They believed that the enforcement of Islamic values in community life requires Dawlah Islamiyah led by a caliph who is democratically elected by the community. ${ }^{21}$ HTI group's ability to enforce change, though a small one, will have long-term effects on Indonesian politics. ${ }^{22}$ Meanwhile, the presence of issues in the public arena concerning and questioning the role of Islam in Indonesia would strengthen the HTI organization. Likewise, the global financial crisis followed by the increase of living expenses strengthened the members' belief that capitalism is un-Islamic and therefore must be rejected. Many reports predicted that the HTI mobilization strategy would increase the influence of HTI organizations in society in the future.

Hizbut Tahrir in Indonesia was introduced by Abdullah bin Nuh, leader of al-Ghazali Islamic boarding school in Bogor, West Java. Abdullah's meeting with one of the Hizbut Tahrir activists who migrated to Australia, Abdurrahman al-Baghdadi, became a pivotal time in the history of Indonesian Hizbut Tahrir. Abdullah was a teacher and preacher who felt disappointed with Islamic organizations in Indonesia in the late $70 \mathrm{~s}^{23}$ and looked for an alternative model of activism and Islamic thought that was for him ideal. This background explains the reason HTI appears as a different socio-religious movement in the political contestation of Muslim organizations in Indonesia, more particularly compare with Nahdlatul Ulama and Muhammadiyah the two dominant and large mass organizations in the country. HTI represents a "transnational Islam" as this "political" organization was not born from the Indonesian local identity struggle but adopted from

\footnotetext{
${ }^{20}$ Marcoes et al., Kesaksian Para Pengabdi, 16-17.

${ }^{21}$ Khusnul Khotimah and M. Abdul Karim, "Hizbut Tahrir sebagai Gerakan Sosial (Pengaruh Hizbut Tahrir di Timur Tengah Terhadap HTI di Indonesia)," (Master Thesis--Universitas Gadjah Mada, 2012).

22 Markas Besar Tentara Nasional Indonesia Pusat Pengkajian Strategis, Menghidupkan Kembali.

23 Burhanuddin Muhtadi, "The Quest for Hizbut Tahrir in Indonesia," Asian Journal of Social Science, Vol. 37, No. 4 (2009), 623-645.
} 
Palestine. $^{24}$ Different from other religious organizations characterized by a tradition of cultural adaptation and assimilation, the socio-political characteristics of HTI tend to emphasize its Arab dimension. ${ }^{25}$

Gorontalo is one of the important sites for the spread of the HT movement. Research informants confirmed that the mushrooming of HT and other religious movements in Gorontalo connects to the culture of the local people who preserve the habit of welcoming strangers and easy to accept and respect differences. Another reason relates with the customary principles embedded in the life of the people of Gorontalo, that is "adati bula-bulaa to saraa, saraa hula-bulaa to Qur'anī", which means "culture based on Laws, Laws based on God's book (the Qur'ān)." In the context of HTI, this principle is easily used as an argument for HTI activists and cadres to convince the public about HTI's goals and ideology to restore and enforce Islamic shari ${ }^{-}$ah and even the Islamic State that fits with people principles.

A study reports that the history of HTI in Gorontalo began in 2009 from the hand of Ihsan Sibali who was an official member of HTI in Makassar. ${ }^{26}$ The target of Sibali's preaching (on HT platform) according to Sukrin Saleh Taib's research was initially focused on the university area, which was considered the right site to disseminate HT ideology and force it to grow faster. Another study referred by Taib shows that the organization of Alumni of Muslim Student Association (Kahmi) invited Sibali to be a speaker at a Political Dialogue Forum under the theme "Quo Vadis Democracy" in 2008. Hence, for the first time, the issue of Khilafah Islamiyah (Islamic state) promoted by HTI was being discussed in the public space in Gorontalo. The data illustrates that the HTI ideology was disseminated in Gorontalo around 2008-2009, or about 20 years after the organization was adopted in Indonesia.

Following Sibali's footstep, his followers established small circles to disseminate HT's ideas and study al-Nabhānī's books,

\footnotetext{
${ }^{24}$ Masdar Hilmy, "Akar-Akar Transnasionalisme Islam Hizbut Tahrir Indonesia (HTI)," ISLAMICA: Jurnal Studi Keislaman, Vol. 6, No. 1 (September 2011), 1. ${ }^{25}$ Ibid.

26 Sukrin Saleh Taib, "Demokrasi Menurut Hizbut Tahrir Indonesia (Kajian tentang Konsep Pemikiran dan Gerakan Aktivis Hizbut Tahrir Indonesia Kota Gorontalo)" (Ph.D Thesis--UIN Alauddin Makassar, 2013).
} 
among them including Shakhsiyah Islämiyah, Fiker al-Isläm, and Nizăm al-Isläm. These circles played a significant role in HTI's effort to spread their ideology and reach out of the State University of Gorontalo to other universities including State Institute of Islamic Religion (IAIN) Sultan Amai Gorontalo, University of Ihsan Gorontalo (UNISAN), University of Gorontalo (UG), Gorontalo Polytechnic (Poligon) and Gorontalo Muhammadiyah University (UMG). ${ }^{27}$ Not only the university communities but the HTI members also targeted private high schools in Gorontalo. An informant reported about an extracurricular program that required all students in a famous private school to attend religious gatherings every night with speakers from and talking about HTI. One of the alumni from that school shared her experience of being indoctrinated about the importance of upholding shari ${ }^{-}$ah and Islamic Caliphate every day. ${ }^{28}$

\section{The Prototype of Being A Man and Woman}

Ideology of Islamic State: Islamic Politic Idealism in Both National and Global World

The social identity process follows three stages involving social categorization, prototype, and depersonalization. ${ }^{29}$ Social categorization has an impact on self-definition, behaviour, and perceptions on prototypes that define behavior. A prototype is cognitive social construction adapted through underpinning differences compare to other groups (metacontrast). Strong metacontrast leads to depersonalization and when depersonalization occurs individuals use group identities to be their self-identities, and hence identical perceptions and thoughts emerge. ${ }^{30}$ Depersonalization creates clear segregation and differentiation between "us or we" and "them or they." A group has the interest to form a prototype to represent the group in a wider social arena. Hence, the prototype is a

\footnotetext{
27 Ibid.

${ }^{28}$ Interview with Lala (pseudonym), a former activist of MHTI Gorontalo, October 19, 2018.

${ }^{29}$ Michael A. Hogg et al., "The Social Identity Pespective: Intergroup Relations, Self-Conception, and Small Groups," Small Group Research, Vol. 35, No. 3 (2004), 254.

${ }^{30}$ Burke and Stets, Identity Theory, 118-119.
} 
cognitive representation of a group's norms and follows the principles of metacontrast and polarization.

HTI members have a distinctive paradigm related to political idealism at global-international and local-Indonesian levels. Referring to the idea of its founder, al-Nabhānī, one of the clear prototypes of the members of this organization is the political idealism to uphold the Islamic Caliphate. They perceive all problems the country deals with nowadays have the same root: the government system that does not implement Islam (their textualpolitical interpretation version of Islam). Hence, in HTI's insights, there is no solution but the Khiläfah Islamiyah (Islamic State) System, which must operate beyond one country but the whole world, as the sole political authority for all Muslims. All HTI members embrace the doctrine of Khiläfah Islamiyah as an ideological antithesis to counter and replace the concept of the nation-state (NKRI) and Pancasila that have been considered the final ideology in Indonesia. ${ }^{31}$ The discourse of "transnational Islam" with the spirit of unifying Muslims all over the world under the Islamic state is politically and ideologically a challenge for the Indonesian state that embraces Pancasila. Indeed, it challenges the existing various religious organizations that emerged from the struggle for Indonesian locality.

HTI members are eager to uphold the Islamic caliphate as the only solution for Indonesia that according to their discernments continues in chaos and disasters due to the country remains under corrupt leaders. The corrupt deeds are believed to a direct result of not implementing the Islamic shari' ${ }^{-} a h$ and it creates everlasting natural disasters and social chaos. The political idealism to establish Khiläfah Islamiyah is clear and becomes one of the most vivid collective identities of all HTI members in Gorontalo, both men, and women. All informants during the interview showed the same characteristics on their motivation and the ultimate goal of their da'wah to fight for the establishment of an Islamic caliphate. ${ }^{32}$ Hence HTI members show a strong level of depersonalization as the group identities become a personal identity. This phenomenon

\footnotetext{
${ }^{31}$ Hilmy, "Akar-Akar Transnasionalisme Islam."

32 Interview with Dara (pseudonym), a woman activist of HTI Gorontalo, October 17, 2018.
} 
also illustrates the metacontrast that differentiates HTI group members and the supporters from those outside their group.

\section{Thought as the Basis for Social Change and Islamic Restoration}

Principles on the enforcement of Islamic fikrah (thought) and Islamic Tariqah (path) signify other powerful prototypes of HTI members. They uphold the idealism that Islamic fikrah becomes the foundation for Islamic awakening. The area and main target of da'wah according to this group is the realm of knowledge (thoughts) which is considered the most urgent in the structure of social change. Systemically, fikrah works to lead to revival as follows:

\section{Fikrah/Thought $\Rightarrow$ Perception $\Rightarrow$ Behaviour $\Rightarrow$ Revival}

The above scheme illustrates that for HTI the most fundamental change is a change in the realm of thought. HTI members, both women and men, believe that thought is the starting point and center of a change. Changes in thought are believed to build motivation to act, revive and uphold the Islamic caliphate. The change in thought in their principle is a change from what they call fikrah jabilizyah (thoughts that do not originate from Islam) to fikrah Islamiyah (Islamic thought).

Fikerah Islamiyah (Islamic thought) embraces the recognition of the prophet Muhammad as a Prophet and Messenger of Allah and to whom every Muslim must follow. The fikrah Islamiyah is believed to automatically foster a love for him more than other humans and anything else in the world. Individual change is accepted to be the starting point for a systemic change on a broader and global scale. Hence, the Islamic system in HTI's design of political contestation is built through a persistent political struggle that started with changes in fundamental fikrah individually and tariqah. ${ }^{33}$ They design the expected changes systematically and gradually, consisting of three stages ${ }^{34}$ that every member must follow. The first stage is tathqif or training and building cadre. The next stage is tafäul or interacting with the

\footnotetext{
33 Taib, "Demokrasi Menurut Hizbut Tahrir Indonesia."

${ }^{34}$ Hizbut Tahrir, Strategi Dakwah Hizbut Tahrir (Bogor: Pustaka Thariqul Izzah, 2000), 57.
} 
community (conducting da'wah) or also known as marbalat tafácul $m a^{\prime} a$ al-ummah (the stage to interact with the community). The final stage is mainly the ultimate goal of the HTI movement, the attempt to take over the political power (istilam al-hukm) which means establishing an Islamic State.

The Khilāfāh Islāmīyah as a Competitor againts Global Secularism and Capitalism

Members of HTI embrace the doctrine of Khiläfah Islamiyah as an ideological antithesis to counter, even replace, the concept of the nation-state of the Indonesian Republic (NKRI) and the state ideology, Pancasila. They locate Kbiläfah Islamiyah vis-a-vis with the concept of NKRI and Pancasila. Every HTI member believes that Muslims are required to think, live and act according to Allah's command as understood in their textual-literal interpretation of one of the verses in the Qur'ān, al-An'ām [6]: 57. They are confident that the Khiläfah system would guarantee the implementation of Islamic law. The Islamic shari'ah and Khiläfah Islämiyah will replace secularism which according to their outlook has been attested to have resulted in the collapse of the Indonesian state.

The members of HTI appraise that Pancasila and all government policies have ignored and are not based on Islamic principles and thus considered to be the root of all problems that Indonesia has to deal with. The idealism of enforcing the Kbiläfah is interpreted as a form of resistance against multidimensional colonialism, including ideological colonialism, which according to HTI continues to pervade in Indonesia. The colonialization of global capitalism force, which is understood as a set of secularism, liberalism, and materialism, is believed to be able to counter by applying the same systemic way, through the global power of the Islamic caliphate. The call to invite Muslims to implement the Islamic sharíah is conducted within a broader framework against the attack of global secularism and capitalism and to accumulate power towards the establishment of the Islamic Caliphate. This da'wah of resistance is promoted as a form of HTI's concern for Indonesia's better future. 


\section{The Khilāfah Islāmīyah as the Only Solution for All Problems}

All HTI members share the idea that all chaos, crises, and misery in the world have occurred due to the Islamic shari'ah has been not implemented. Hence, they criticize the contemporary issues from domestic up to regional levels and even international and locate them as the basis of their arguments for promoting the Islamic State as the only solution. Domestic issues have included the issue of violence against women and children, holding again the argument that the problems merely were resulted from the negligence of Islamic shari'ah. They also have a concern on social issues including poverty and associate the issue directly with capitalism and state policies which in their view are not based on Islamic law.

HTI members believe that the source of all problems is simply the failure to implement Islamic shari' ah and thus they insist that the implementation of Islamic shari'ah through the establishment of the Islamic state will lead all people to live a prosperous and happy life. This belief further encourages the members of this group to learn Arabic to be able to read the book written by alNabhānī, which has become the primary source of knowledge and preaching. Informants stated that the reason they hold the books to be their single source of knowledge was simply due to the difficulty of reading the books as they do not have a background in the Arabic language. Others argued that maintaining a single source is an effective strategy to avoid conflict between the members.

\section{Anti-Violence Jihad}

Another important and interesting prototype of HTI group members is embracing the principle of jibäd without violence. The members share the idealism that jihäd in the form of calling people to implement Islamic shari'ah without violence and establishing the Islamic caliphate is carried out through various strategies. The da'wah strategies which are primarily a form of resistance against the state ideology include demonstration, holding forums to raise public awareness and disseminate the urgency of the Islamic Caliphate, conducting regular group discussions, and preparing cadres. The members believe that violence can only be the 
authority of the state, the Islamic Caliphate, when it has been established.

The members expressed their hidden and public transcript to the power of the state based on their collective idea that Muslims must survive under the colonial-infidel ruler who ignored Islamic values. Muslims nowadays in their insight is in a position to survive from the attacks of secularism, liberalism, modernism and other isms considered to be contradictory to Islam. In this stage, a member of HTI informed that violence is occasionally needed because it is to defend Islam. Indeed, Pancasila is perceived as being corrupted because the rulers inserted the Pancasila with infidel values. Hence, they insist that Muslims must seize Pancasila and bring that back to Islamic values.

\section{Strategy and Symbolic Contestation Through Hidden Transcript}

Following James Scott, the political life of subordinate groups is generally not found in either a public collective resistance or in complete hegemonic obedience, but lies between these two opposing poles, ${ }^{35}$ called "hidden resistance." Resistance can be categorized into two forms, namely open (on stage or public transcript) and closed/hidden (offstage or hidden transcript). The difference in "onstage" and "offstage" behavior shows the extent to which "false respect" is expressed in the public sphere where power relations are often negated, compared to offstage which is a private space. Open resistance is expressed openly, there is open interaction between subordinate groups and the dominant ruling group and is carried out systematically and well organized.

In contradiction to open transcript, hidden resistance is symbolic or ideological, intended to give meaning to categories that exist in society. Scott explains the hidden resistance in a simple definition as the discourse that takes place "offstage," beyond direct observation by powerholders. The hidden transcript is thus derivative in the sense that it consists of those offstage speeches, gestures, and practices that confirm, contradict, or inflect what appears in the public transcript. ${ }^{36}$ The hidden resistance occurs outside the stage or space of domination and beyond the

\footnotetext{
${ }^{35}$ Scott, Domination and the Arts of Resistence, 136.

${ }^{36}$ Ibid., 5.
} 
observation of the dominant group. Resistance takes the form of lectures or talks outside the talk of dominant groups, movements, and various practices that confirm, oppose or influence the dominant discourse in the public sphere. The hidden resistance can be found in daily life practices indicated by less systematic, poorly organized, and more individualized procedures.

The resistance according to Scott does not refer merely to fighting over a job, position, money, or other material things. More than these, resistance means a struggle over symbols, ${ }^{37}$ the meaning of the used symbols, the struggle for how the past and present are understood, interpreted, and labeled. Resistance is a contestation to interpret history, identify causes and assess mistakes. It is a struggle to give meaning to local history. Resistance represents class conflict and the extraordinary thing about such a conflict and the extent there are common grounds of world view. In the context of HTI, this group shows both hidden and public resistance. Yet, the formal dissolution by the Government has encouraged this group to create innovative changes in terms of strategy and forms of resistance, as described in this paper later.

Da'wah as Arena of Resistance: "Interpreting Every day life" and Implementing Ritual Discipline

Da'wah plays as an effective resistance strategy as the main target of HTI group is shifting paradigm in the realm of knowledge or discourse that underlies people's daily practices. The HTI members express their resistance through strategy and model of da'wah that consistently raises daily issues that are relevant and contextually the people deal with. They interpret every problem in daily life as a failure or at least an impact of government policies or communities that are deemed not to implement Islamic shari'ah. Hence, again, that the only solution they convince people to struggle for is to uphold the Islamic Caliphate. The members of HTI admitted that their resistance in the form of interpreting each social problem as a form of failure of the Government or society that ignores Islamic shari'ah has attracted a lot of sympathy from the people, particularly because they consider HTI to teach them the "true" Islam and promise a better change in the future.

${ }^{37}$ Scott, Weapons of the Weak, xvii. 
The narratives they developed within da'wah activities illustrate their interpretation of the existing reality as the failure of the Government or the "infidel" society. The meaning and labeling of the Government as an infidel (unbeliever) exemplify HTI's symbolic resistance to the ruling Government. The implicit goal of this ideological contestation is not merely to build people's beliefs but to control, or in Scott's terms, to control with belief. The goal of this group to control the people's knowledge is successful when they succeed in shaping behavior. In the context of HTI, they are successful when they constructed people's perspectives concerning "problems that currently exist as the failure of the infidel Government," and later affect people behavior.

The da'wah targets also the youths and illustrates a clear form of hidden resistance (hidden transcript). The HTI members precisely adjust da'wah material to the world of teenagers' life, for instance, da'wah on dating issues. From talking about dating they invite teenagers to return to the true teachings of Islam as HTI's interpretation and leave the dating. They employ contextual, relevant, and empirical strategies, by bringing the audience to a discussion about their life experiences and realities they see and experience in their surroundings and interpret them in political framing. Several social problems including high rates of abortion, early marriage due to unwanted pregnancy happening to teenagers or children, domestic violence, and LGBT are interpreted as failures resulted from practices that ignored Islamic norms.

HTI members also bring a simple theme like inviting people to carry out daily obligations or rituals as a Muslim: five times praying on time. They claim that their calling for conducting prayers in a disciplined manner made this group easily accepted and received recognition from the community. The members perceive this calling for prayer as one of the benchmarks to locate HTI as a good and religiously consistent organization. Hence, emphasis on transcendental and individual rituals on the one hand and the other hand the inculcation of the doctrine of kajfir governments as the single root of all problems illustrates HTI symbolic resistance strategy. The members confirm that this calling people action has led HTI to be easily accepted in society in Gorontalo. They deem that the banning from the government does not change this social recognition. 
HTI activists and members were actively present in the cultural events in the community. They joined religious gatherings, rituals, and events including the Isrä' Míräj celebration (The Ascension of the Prophet Muhammad), halal bi halal (gathering to ask for forgiveness during Idul Fitri celebration), Religious gathering, and other religious events in Muslim communities. They functioned these arenas to recruit members, led people to connect and interpret what they see and hear with the failure of the Government and democracy as well. They eventually offered people to have an opportunity to learn and understand religion more intensively. The research informants informed how they built communication with peoples, then asked for contact numbers and invited them to meet again to follow up on conversations or discussions about religion in more depth. ${ }^{38}$

\section{Family as the Basis Arena for Symbolic Resistance}

HTI members, male and female, utilized an effective communication pattern and network of nuclear and then extended families, ${ }^{39}$ as strategies in disseminating and preserving religious thoughts, group identity, and political ideology. The study found one of the extended families consisting of a mother, two daughters, a son, and a daughter-in-law whom all became active members of HTI and some were activists. They acknowledged that HTI or MHTI taught them the correct Islam as it invited people to be consistent in practicing Islam, including praying five times on time. These findings illustrate that family has a significant role in determining the sustainability of HTI ideology and religious understanding. The dissemination of ideology in family institutions enables family members to inherit and perpetuate ideology as well as religious interpretations, norms, and practices. The symbolic resistance through locating in binary opposition between the "true Islam" versus "corrupted Islam" remains an effective strategy.

\footnotetext{
${ }^{38}$ Interview with Syamsi, lecturer of Universitas Nahdlatul Ulama and researcher for HTI, Gorontalo, November 18, 2018.

${ }^{39}$ Muhammad Firdaus, "Pola Komunikasi Aktivis HTI dalam Mengembangkan Dakwah Islam,” Jurnal Ilmu Komunikasi, Vol. 8, No. 3 (June 2018), 328-339.
} 


\section{Campus, Schools, and Government Institutions as Resistance Fields}

Friendship and working partners became another target of HTI da'wah for resistance. The members of HTI, more particularly university lecturers or students, effectively used their networks to expand HTI idealism within the campus arena. This study found a boarding house occupied by HTI members. There were also stories about non-HTI students, who joined HTI religious gatherings, brought HTI's ideological point of view and narrative in their Non-HTI organization circle or discussion. HTI members recognized this strategy as proper and effective because HTI provided answers (narrative) to innumerable problems of daily life. They discussed and explained actual problems that later became a reference for other organizations that usually do not have such systematic, actual, and regular studies as HTI circles.

Apart from bringing in HTI's narratives and ideology to other organizations, another popular strategy was to invite close friends to join the circles held by HTI groups. This recruitment approach was in line with the HTI narrative that the organization is open for all Muslims regardless race, color, or school of thought. The members perceived that teenagers and young people have an important role and become a social capital that would determine the success of dissemination of group's political narrative and ideology. Youth was located as an important entity in the continuity of a generation and became an important agent in fighting for the enforcement of the Islamic state in Indonesian. The study found that there was a Senior High school that required all students to take an extra curricula program on Islam directed by HTI. The school developed a systematic and well-structured program that was designed for all students to take. During the fieldwork, one of the school's alumni, Lili (pseudonym), told us how all students were systematically introduced to HTI's thoughts and ideology every day. This phenomenon illustrated the importance of teenagers as HTI targets in Gorontalo.

Indeed, many reports informed the symbolic and hidden resistance of HTI at schools in other regions that were carried out systematically not only through extracurricular activities but also in cooperation with government agencies. Several HTI activities were reported to be held in collaboration with government agencies as 
found in HTI publications. ${ }^{40}$ In 2009 for example, HTI collaborated with the Government Education Office of Pasuruan to organize extracurricular activities on Islamic courses at schools. In Ngawi, Central Java, HTI collaborated with the Education Office to conduct training on reproductive health in several schools. The same collaboration was also held in Bogor to conduct training on teaching of Islamic history for teachers. Center for Religious and Cross-Cultural Studies (CRCS) Gadjah Mada University reported that HTI had even more freedom in Papua due to the discourse of Islamization echoed by the military was strategic to counter the discourse on independence.

\section{Public Transcript as Direct Resistance before the Banning} Spirit of Debate and Physical Fight in Public Arena

The political agendas of HTI activists were very prominent in public spaces particularly before the government legally disbanded the organization in 1917. The activities included holding series of seminars, panel discussions and small circles in many universities and even schools, tabligh akbar (gala missionary meeting) in society, and the HTI Manifesto ${ }^{41}$ which was publicly opened. HTI members expressed the spirit to uphold Islamic shari'ah openly, built counter narratives over models of religious and political implementation in the country, and interpreted problems as direct failures that resulted from rejecting Islamic shari'ah as their interpretation. They opposed modern values and claimed the failure of modernity that was perceived as Western byproduct, while at the same time considered government of Indonesia and its policies as part of modern agenda. The members, both male and female, have similar courage and skill in building argument as the organization gave an equal role in public domain to both men and women as the warriors for the establishment of the Islamic State. This principle became the basic reason for each member to dare to debate and openly embark on their resistance.

\footnotetext{
40 Center for Religious and Cross Cultural Studies (CRCS), "Haruskah HTI Dibubarkan?," Berita, available at https://crcs.ugm.ac.id/haruskah-htidibubarkan/ accessed on May 5, 2020.

${ }^{41}$ Hizbut Tahrir, Struktur Negara Khilafab: Pemerintahan dan Administrasi (Jakarta: HTI Press, 2008), 12.
} 
In addition to seminars, workshops, or public discussions HTI members, more particularly young members, expressed their resistance and echoed narratives about the importance of the Islamic caliphate in classrooms at universities including state universities. The activists were well-known for their prominent visibility and vocality in the classrooms. They had skills to select appropriate dictions, mastered actual issues and problems, and were well trained to interpret and relate every problem to sociopolitical-religious issues and hence the failure of the Government. The diction, epistemology, model of analysis, and homogenous narratives of the members of this group indicated the group's comprehensive capital for the sustainability of the institution. Some of the activists confirmed that they have courage was not only for intellectual fighting but also fighting physically for the sake of enforcing Islamic shari'ah and the establishment of an Islamic caliphate.

The open resistance on campuses was also expressed in the form of the regular study group (halaqab). In the context of Gorontalo, several targeted campuses to spread the group ideology included Gorontalo State University, IAIN Sultan Amai Gorontalo, Ihsan Gorontalo University. The student activists in these campuses called themselves an organization of the Gorontalo Liberation Student Movement (Gema [Echo] of Liberation) with the central office at Sultan Amai State Institute of Islamic Studies (IAIN) of Gorontalo. ${ }^{42}$ The activists even controlled the campus radio in this university for several years and used it as an effective medium to spread the group's thoughts and ideology. ${ }^{43}$ Seminar rooms, discussion forums and, debates events on campus became the mechanisms for recruiting members. The resistance was not only aimed at the state but also the community or organizations they considered misguided.

Not only in various seminars, workshops, or public discussions this group echoed narratives about the importance of the Islamic caliphate, but resistance was also found in classrooms at universities. HTI or MHTI student activists are prominent and vocal in the classroom. They have the skills to process words,

\footnotetext{
${ }^{42}$ Interview with Syamsi, Gorontalo, October 18, 2018.

43 Interview with Afan (pseudonym), a lecturer at an Islamic university in Gorontalo, Gorontalo, October 19, 2018.
} 
master various actual existing problems, and the expertise to narrate and interpret them as socio-political-religious problems and the failure of the Government. The selection of diction, epistemology, and analysis model as well as relatively uniform narratives of the members of this group are one of the capitals for the sustainability of the institution. Some of the activists have even stated that their courage is not only fighting brains but also to fight muscles, before being disbanded, in the name of enforcing Islamic sharî ${ }^{-6}$ and towards the establishment of an Islamic caliphate.

\section{Demonstration on the Roads: Echoing Resistance against the Government}

Open resistance against the Government or other groups became one of the collective identities of HTI organization, mainly before disbandment. Activists and members of HTI were known for their courage to go down to the streets to protest the Government policies and everything considered unfair or contrary to Islam as they uphold. Activists and members of HTI, including in Gorontalo, walked down to the roads holding banners or papers voicing their insights on actual issues happening at regional, national, and even international levels. They held demonstrations showing HTI's attributes to directly reject government policies that were deemed to be against people's side and non-Islamic. HTI activists in Gorontalo City did not even vote during the election of regional officer (Pilihan Kepala Daerah or Pilkada) in April 2013.

They took advantage of various events or celebrations both at the national and international levels. Among the actions was held at the front area of the Hotel of Indonesia in the national commemoration of Youth Pledge Day. They reminded the young generation that globalization and modernization had given birth to an un-Islamic culture and caused many serious problems for the nation. ${ }^{44}$ They hold peaceful marches, campaigned for the enforcement of Islamic law and the establishment of the Islamic State, ${ }^{45}$ against the miss universe event, beauty contests, violence against children, poverty, and other current issues. They shouted voicing anti-coalition with secular groups and rejecting the vote

\footnotetext{
44 See at https://www.panjimas.com/citizens/2017/02/21/khilafah-dan-pendi dikan-menghidupkan-kembali-masa-keemasan/; or at http://www.tribunnews. com/metropolitan/2015/12/16/aksi-damai-muslimah-hti-untuk-palestina.

${ }^{45}$ Hizbut Tahrir, Struktur Negara Kbilafah, 12.
} 
during the election. ${ }^{46}$ Demonstrations as a form of open resistance were in line with the idealism of the organization to awaken, unite and liberate Muslims from the domination of non-Muslim rulers and non-Islamic states. ${ }^{47}$ Resistance was carried out systematically through preparing the agents of change and instilling them with the knowledge, communication, debate skills, and commitment they need to make fundamental changes.

\section{Perpetuation of Collective Identity and Ideology} Metacontrast and Depersonalization of Group Individuals

The formal banning of HTI by the Government does not diminish the depersonalization of individuals in the group. The mechanism of perpetuation of group identity and the ideological process has run systematically through numerous strategies that effectively ensured the sustainability of the organization.

The banning of HTI organization did not have an impact on the members' ideology and idealism of establishing an Islamic Caliphate, as well as on the depersonalization of members and supporters of the organization. The members have internalized the identity and even showed a strong metacontrast that gave rise to depersonalization level. The depersonalization was noticeable from the stories told by the members. A strong prototype marked the collective identity of each member so that each individual identified himself or herself with the identity of the group. Hence identical identities emerged and made the members of this organization easily recognized and distinguished from people outside the organization. Such a strong group prototype would certainly not fade and remain sustainable even though this organization was formally dissolved.

In the context of female members of HTI, women's clothing had become one of the normalized and perpetuated collective identities. The uniformity of source of knowledge, paradigms, narratives, norms, attitudes towards the Government, and even dictions that were operated in their communication enabled the sustainability of the HTI organization and the compliance of its

\footnotetext{
46 Sapto Waluyo, Kebangkitan Politik Dakwah (Bandung: Harakatuna Publishing, 2005), 58 .

${ }^{47}$ Muhammad Muhsin Rodhi, Tsaqofah dan Metode Hizbut Tabrir dalam Mendirikan Negara Khilafah (Bogor: Al Azhar, 2012), 32.
} 
members. Hence, symbolic resistance continued in the form of interpreting socio-religious and political issues as the failure of the state that did not formalize Islam in the social and political orders of the country. The public sphere was no longer the arena for resistance after the banning, but the symbolic resistance remains continued. As Scott confirmed that even though they do not fight overtly, it doesn't mean there is total obedience because there is hidden resistance that keeps on living.

\section{Single Source and Authority in the Structure of Group Epistemology}

Uniformity and single reference as a source of knowledge became one of the strengths in the mechanism of preserving the members' knowledge, norms, and identity of the HTI group. Uniformity of source of knowledge and method of understanding in the structure of members' epistemology helped to lock their thinking and paradigm and led to the uniformity of the narratives they built, the norms, and the actions. The uniformity of knowledge sources that were considered authoritative became an effective means to control the perpetuation of this knowledge. It also fostered and maintained members' compliance with their leaders and protected the collective ideology of the group while at the same time ensured sustainable practices and behaviors. The sustainability of knowledge, ideologies, norms, and practices ensured the continuation of the group or organization.

All informants in Gorontalo acknowledged the works of alNabhānī as their source of knowledge and reference. They read or studied to understand the books and referred to that book in their regular study groups and activities as well. They believed that a single source played a very important role in their attempt to avoid internal conflict and minimize the emergence of different thoughts as well as debate and different narratives among group members. The principle of escaping from conflict and internal debate became one of the strategies that were considered urgent in this group. In the context of resistance, the internal conflict will affect group strength and can destabilize the individual's depersonalization that has gone well. A single source guaranteed the same thoughts, visions, and narratives, and it was even considered normal. Normalization runs as smoothly as being 
justified by the existence of beliefs and interpretations of religious teachings and values which were considered final and the truest.

Observations and interviews with all informants confirmed the existence of thoughts and principles about the urgency of a single source. TR (one of the informants), who was busy with her daily duties as a lecturer and a mother of three children, argued that a single source of knowledge was obligatory to building comprehensive religious thinking and understanding. DR, HTI activists who remained single, and TR admitted that they referred to a book written by al-Nabhānī in its original version in Arabic. They confessed that they did not have the capability in reading Arabic and thus must learn Arabic relying on a dictionary as they were required to be able to read the original version of the book. The activists admitted that even reading one book was difficult due to language barriers and hence they did not have another book as a reference.

\section{Systematic Counter-Narrative}

HTI members believed that the truth that was considered divine and hence final would not fade away only because of rejection or opposition from humans, including the Government. The dominant narrative among the group members had been that truth must be defended and whoever opposes it considered to be against Allah. Anyone who disagreed with or was hostile to HTI was considered inimical to Islam and Islamic sharíah. The disbandment by the Government to a certain extent strengthened the members' belief in the infidelity of the government its position against Islam. The disbandment was "interpreted" as an indication of the government's hostility towards Islam and the rulers' opposition towards Islamic teachings and values. In other words, formal disbandment did not influence the HTI group prototype at the level of paradigm, ideology, and norms. Disbandment even reinforced the prototype of the group and the individual depersonalization of members. On the Government side, the President, Joko Widodo, developed public scripture that the disbandment was based on suggestions including the Ulama. ${ }^{48}$

48 Dames Alexander Sinaga et al., "Gov't Officially Disbands Hizbut Tahrir
Indonesia," Jakarta Globe (July 19, 2017), available at https://jakarta 
The members continued to disseminate the ideology of enforcement of Islamic sharí ${ }^{-6}$ ah and the Islamic caliphate after the banning, echoing the narrative about the chaos and decline of the country and promoting the Islamic state as the only ideal solution. Hence, the disbandment was interpreted as a Government's resistance against an effort to uphold God's law. All informants, therefore, confirmed that the disbandment did not stop their footsteps and would never change their thoughts, ideologies, and dreams to uphold the Islamic Caliphate. Indeed, according to Syamsi's participatory observation research, ${ }^{49}$ HTI activists had argued that the Government's disbandment could not change the fact that this earth belonged to Allah for mankind and hence everyone has the right to live in.

\section{Strategy of $\mathrm{Da}$ 'wah and Society Acceptance}

The government's disbandment did not affect HTI members' da'wah activities on the grass-root level, as an important part of their symbolic resistance strategy. Their dawah in Gorontalo society continued to run as usual although the community knew about the formal banning. They developed a dominant narrative about their effort of spreading true Islam and hence people did not inquire about their association with a disbanded organization. Some observers and researchers from Gorontalo informed that HTI activists were smart in selecting a strategy to approach society: building narratives of "inviting people to follow the true Islam and implementing consistent rituals" on the one hand, and on the other hand, narratives about a better future change by enforcing the Islamic caliphate.

HTI activists also did not demonstrate tangible group identities including clothing styles (some other Islamist-conservative groups wore white trousers, white robes, or burqa for women), beards, or the practice of polygamy. ${ }^{50}$ Their physical appearance conformed to common people in the local community tradition. As aforementioned, the collective identity of this group was more

globe.id/context/govt-officially-disbands-Hizbut-tahrir-indonesia accessed on February 16, 2021.

${ }^{49}$ Interview with Syamsi, Gorontalo, October 17, 2018.

50 Focussed group discussion with researchers and academics from Islamic universities in Gorontalo, October 17, 2018. 
dominant in the realm of thought, ideology, and disciplining religious ritual practices such as praying on time. Hence, in contrast to other Islamist-conservative groups that embraced distinctive physical characteristics and practices and against the mainstream in the traditions of society, HTI members did not express different appearances. This identity allowed this group to be more easily accepted in society and engaged in various socioreligious activities at the grass-root level.

\section{Change of Resistance Strategy after Disbandment Reinforcement and Continuation of Hidden Transcripts}

The Government's official revocation of HTI did not have a significant impact on the members' way of thinking, narrative, and group identity as well as their political idealism. Yet, the disbandment led them to change the field of resistance, the shift in the da'wah space as a symbolic resistance strategy for HTI activists from a large public arena to more limited space. The disbandment prompted this organization to make changes in the strategy and pattern of resistance in their attempt to uphold the Islamic Caliphate. HTI activists were previously very active and visible in the public with their various large events involving a wide audience. They even enjoyed free air in open spaces that were easily accessible to rulers who became the target of criticism and resistance. However, following the disbandment activists no longer hold large activities and public resistance in society, campuses, or schools as their bases for disseminating and fighting against state ideology.

A particular prototype of locating campuses and schools as the basis for open resistance, disseminating HTI, and recruiting new members had changed after the banning. Although da'wah and circle activities remain perpetuated among students and activists, the visibility and echoes of the HTI group were not as prominent as before they were disbanded. Activities conducted by the activists or symbols that relate to the group disappeared from the public arena. Besides, HTI followers no longer showed their courage to speak out in the public or argued with those who have different views. The enthusiasm to enforce sharíah remain durable, but Government's revocation had led them to be invisible and move to fight with what Scott calls "secret or hidden" 
resistance. Some informants even canceled the appointments to meet with us after receiving instructions from their seniors to be more careful to talk about their organizations to "strangers."

After the disbandment, HTI activists focused more on hidden resistance through da'wah in small circles on campus as well as in grassroots communities and engaging in several socio-religious activities in society. Apart from religious activities and circles, individual hidden transcripts continued to happen. Activists kept disseminating HTI narratives of resistance and political ideology to individuals, by visiting friends' homes door to door or those who were targeted for recruitment. Some activists spoke up with enthusiasm about how they came to the boarding house or house of the candidate to recruit. This door-to-door strategy was commonly used by HTI in their attempt to recruit new members and had been carried out even before the HTI organization was formally disbanded and was currently became a smart strategy after dissolution. In addition to hidden resistance through a door to door, another continuing strategy was holding limited meetings. Activists in Gorontalo informed that after the disbandment they held liqa $\bar{a}$ (meetings) through personal and friendship-connection approaches. The majority of informants described the process of entering the organization because of friendship. Hence liq $\vec{a}$ and media played a significant role to execute recruitment patterns using the peer approach. This pattern remained continued and believed to be strategic after the banning, particularly since the pattern was invisible but effective.

Many activists shared their initial experience of getting in touch with HTI and being recruited through friendship on campus. They knew HTI from a friend and someone they met at the campus, and then they joined HTI religious circles. Some of them got involved when became new students and had to go through an adaptation process with the new atmosphere of the campus. They lived close to other students who had joined HTI, especially because in 2014-2015 many students affiliated with HTI. The HTI activists then invited them to take part in the HTI circles, gave pamphlets, and invited them to attend, while some gave a book on "Say No to Valentine Days." The Government's banning did not affect the friendship channel in the recruitment pattern, because it was invisible and out of public space. This finding was in line with 
the editorial analysis of the voice of Islam who predicted that the HTI activists or supporters of the caliphate will return to their old pattern of being an underground movement and enlarge the group through hidden circles. ${ }^{51}$ In the context of the underground movement pattern, the friendship strategy was more effective in sustaining the movement and recruiting new members.

\section{Integrating or Transforming other Organizations}

Government official revocation of HTI led the activists to join back to his or her previous organization and disseminate his or her new ideology. Some of them brought and integrated HTI ideology and their symbolic resistance in their new current organization. One of the heads of the Female Muslim Student Association (Kohati) shared her experience bringing the HTI paradigm into Kohati regular discussions. One of the relevant themes she acquired from HTI was on headscarves. She confessed that in contrast to HTI culture Kohati did not have regular religious gatherings wherein the members discussed popular-actual issues including the issue of the hijab. ${ }^{52}$ She confirmed that HTI is Islam, based on the Qur'ān and Hadīth and hence she believed that she only disseminated Islam as being taught in HTI.

Integration into other organizations, dissemination and perpetuation of HTI ideology and narratives after the banning took place in a variety of patterns. Among the findings included firstly returning to mainstream organizations that were legally recognized by the state but theologically not against HTI, even though they were different in terms of politics. Among the activists we met, some returned to the Muslim Student Association (HMI), Muhammadiyah, and even Persis organizations. The second pattern was to bring and operate HTI's thoughts, narratives, and ideology in the organizations they followed now as being aforementioned. The third pattern was to perpetuate and embrace HTI's thoughts and ideology in their individual lives and

51 Redaksi, "Strategi Perjuangan 'Khilafah' Pasca Pembubaran HTI, Waspadalah!," Suara Islam, at http://www.suaraislam.co/strategi-perjuangankhilafah-pasca-pembubaran-hti/ accessed on June 22, 2018.

52 Interview with Laila, activist of Kohati and former activist of MHTI, Gorontalo, October 18, 2018. 
locate them away from the organization they currently belonged to.

\section{Formally Quit, Yet Ideologically Remain HTI}

In addition to restricting the space, patterns, and targets of da'wah, another prevalent strategy carried out by activists or members of HTI after the banning was to declare formally to be no longer active or withdraw from HTI membership by sending a formal letter to whom it may concern. Many activists with their respective status of being Civil Servants (Pegawai Negeri Sipi) declared their resignation from the HTI organization by sending their resignation letters to HTI Institution. One of the activists we interviewed worked as a civil servant lecturer at a state university in Gorontalo and taught a course on State Ideology of Pancasila. He stated that he was no longer active in engaging in HTI activities after the Government's official renovation. He shared how to teach Pancasila, that in his insight had been injected with nonIslamic values and hence Muslims have to take over Pancasila from the infidel rulers and insert Islamic norms and values in the body of Pancasila. He was no longer active, yet he remained eager to protect HTI students who continued holding religious circles on campus after the banning.

Some activists worked as leaders in the Office of Marital Registration and eventually resigned formally from HTI. Some others worked as regional government officials and sent a resignation letter after HTI revocation. Yet, the formal resignation and discontinuity from various HTI activities in the public sphere did not directly mean a change in their paradigm, beliefs, and political idealism. HTI's thoughts and idealism continued to dominate the members' discourse of knowledge and their spirit of preaching had never extinguished just because of the formal revocation. The Government formal revocation had an obvious impact primarily on the existence and resistance pattern of HTI in the public sphere and government institutions. Various activities in public spaces, previously even utilizing public facilities and spaces including mosques and university rooms, were no longer held. Yet, da'wah and symbolic resistance to state ideology and Government policies continued because the ideology and idealism of 
establishing an Islamic caliphate remained lasting in the hearts of its followers.

\section{Conclusion}

HTI members internalized strongly collective identities of the group and hence the individuals experienced depersonalization and identified her or himself with the group identity. The prototypes in this group expressed uniformity of ways of thinking, narratives, ideologies and political idealism, and norms as well as the practices in the members' daily life. The members of the group demonstrated the same identity and at the same time were very distinctive from members of other groups or "metacontrast." The metacontrast encouraged the emerge of self-depersonalization and led the identity of its members to be quite easily recognizable and distinguished from those outside the group. The collective identities of the HTI group were found to be more cognitive and normative, and hence the prototypes were noticeable in the narratives and the dictions, the points of view, and the norms that regulated the member's behaviors.

The collective identity of the HTI group emphasized the cognitive level of thought, discourse, and ideology and did not focus on physical appearances and distinctive clothing or practices. Identity at the paradigmatic level included the dominant idealism of enforcing the Islamic caliphate as the only solution for sociopolitical chaos and disturbance and upholding Metaphysical Islamic Thought as the foundation for Islamic awakening. Besides, consistency with the use of a solitary source of knowledge had fostered and maintained the obedience of members to their leaders as well as the collective ideology of the group. At the same time, it guaranteed the homogeneity and perpetuation of knowledge, norms, practices, and behaviour and ensured the sustainability of the life of the group. The compliance and sustainability mechanism explained how the formal revocation of HTI by the Government did not have a significant impact on the way of thinking, ideology, and group identity as well as the political idealism of HTI.

The dominant narrative had been that the divine truth was final and would not fade just because of rejection or opposition from humans. Anyone who opposed the truth was considered to be against God and whoever disagreed with or was hostile to HTI 
was then considered hostile to Islam and Islamic shari'ah. The Government's disbandment was interpreted as the government's opposition to Islam.

The government's formal revocation of HTI organization had an impact mainly on HTI's space of resistance and da'wah patterns as a symbolic resistance against state ideology and socio-politicalreligious understanding and practices that were considered unIslamic. The impact of the banning was limited to the shift in the da'wah space from a large public space to more restrained groups or communities. Da'wah and religious circle activities spreading the narrative of resistance remained continued in campuses, but their visibility and echoes were no longer heard. Before the disbandment, the resistance was carried out openly (public transcript), well organized and systematically managed. Yet, after the banning resistance was expressed secretly in a limited space or at the individual level (hidden transcript), through forums, rituals, and religious celebrations in the grassroots community as well as educational institutions. The friendship approach and door-todoor visits to recruit new members became relevant mechanisms that did not invite a reaction from the authorities. Another new approach was to encourage members to become civil servants and join government agencies, which were previously discouraged.

The patterns in perpetuating ideologies, narratives, and organizational idealism after the banning had been various. Apart from changing the resistance strategy from public to hidden resistance, another pattern was to integrate HTI ideology into their current organization or transformed it. The integration into other organizations included: first, returned to mainstream organizations that theologically fitted with HTI even though different in political agenda. The second strategy was to operate HTI thoughts and ideologies in the organizations they followed, and the third strategy was to apply HTI thoughts and ideologies in their individual lives without incorporating them into the organizations they currently belonged to. Another pattern was by formally just leaving out the HTI organization. Hence, the formal banning of HTI organizations had a significant impact on the HTI space and strategy of resistance. However, on the one hand, the da'wah and religious circles as an effective mechanism of preserving the ideology and symbolic resistance to State ideology remain 
perpetuated in society. On the other hand, the narrative of inviting to the true Islam through a strategic approach and politically distinctive interpretation of HTI concerning daily life, and the discipline of rituals helped this organization to have a respective place in the heart of society. Hence the formal disbandment would no affect significantly this situation and the Government needs to find a more strategic way to be able to change HTI members' political ideology and idealism.

\section{Bibliography}

\section{Books, Articles, and Websites}

Abdullah, Anzar. "Gerakan Radikalisme dalam Islam: Perspektif Historis," ADDIN: Media Dialektika Ilmu Islam, Vol. 10, No. 1, 2016.

Abdullah, Kurniawan. "Hizbut Tahrir Indonesia (Gerakan Politik Islam Ekstra-Parlementer)," in Imam Tholkhah and Neng Dara Afifah, Gerakan Keislaman Pasca-Orde Baru, Upaya Merambah Dimensi Baru Islam. Jakarta: Balitbang \& Diklat Keagamaan Depag, 2005.

Ahyar, Muzayyin. "Membaca Gerakan Islam Radikal dan Deradikalisasi Gerakan Islam," Walisongo: Jurnal Penelitian Sosial Keagamaan, Vol 23, No. 1, 2015.

Asrori, Ahmad. "Radikalisme di Indonesia: Antara Historisitas dan Antropisitas," KiALAM, Vol. 9, No. 2, 2015.

Burke, Peter J. and Jan E. Stets, Identity Theory. New York: Oxford University Press, 2009.

Center for Religious and Cross Cultural Studies (CRCS), "Haruskah HTI Dibubarkan?," Berita, at https://crcs.ugm. ac.id/haruskah-hti-dibubarkan/ accessed on May 5, 2020.

Editorial. "Tanggapi Data Mahfud MD di ILC, Mantan HTI Jelaskan Jumlah Anggota HTI Hanya Segini,” Duta Islam, at https://www.dutaislam.com/2018/06/tanggapi-data-mahfudmd-di-ilc-mantan-hti-jelaskan-jumlah-anggota-hti-hanyasegini.html accessed on June 08, 2018.

Firdaus, Muhammad. "Pola Komunikasi Aktivis HTI dalam Mengembangkan Dakwah Islam," Jurnal Ilmu Komunikasi, Vol. 8, No. 3, June 2018.

Focussed group discussion. Gorontalo, October 17, 2018. 
Hilmy, Masdar. "Akar-Akar Transnasionalisme Islam Hizbut Tahrir Indonesia (HTI)," ISLAMICA: Jurnal Studi Keislaman, Vol. 6, No. 1, September 2011.

-----. "Radikalisme Agama dan Politik Demokrasi di Indonesia Pasca-Orde Baru," MIQOT: Jurnal Ilmu-Ilmu Keislaman, Vol. 39, No. 2, 2015.

Hizbut Tahrir. Strategi Dakwah Hiæbut Tahrir. Bogor: Pustaka Thariqul Izzah, 2000

----. Struktur Negara Khilafah: Pemerintahan dan Administrasi. Jakarta: HTI Press, 2008.

Hogg, Michael A. et al. "The Social Identity Pespective: Intergroup Relations, Self-Conception, and Small Groups," Small Group Research, Vol. 35, No. 3, 2004.

http://www.tribunnews.com/metropolitan/2015/12/16/aksidamai-muslimah-hti-untuk-palestina. https://www.panjimas.com/citizens/2017/02/21/khilafah-danpendidikan-menghidupkan-kembali-masa-keemasan/ Jasso, Guillermina. Identity, Social Identity, Comparison, and Status: Four Theories with a Common Core. New York: New York University, 2002.

Jenkins, Richard. Social Identities. London: Routledge, 2004.

Khotimah, Khusnul and M. Abdul Karim. "Hizbut Tahrir sebagai Gerakan Sosial (Pengaruh Hizbut Tahrir di Timur Tengah Terhadap HTI di Indonesia)." Master Thesis--Universitas Gadjah Mada, 2012.

Kompas.com. "Kemenkumham: Pembubaran HTI Berdasarkan Data dan Fakta," at https://nasional.kompas.com/read/ 2017/07/19/10553011/kemenkumham--pembubaran-htiberdasarkan-data-dan-fakta?page $=$ all accessed on October 21, 2017.

Madjid, Nurcholish. "In Search of Islamic Roots for Modern Pluralism: The Indonesian Experiences," in Mark Woodward (ed.), Toward a New Paradigm; Recent Developments in Indonesian Islamic Thoughts. Temple, Arizona: Arizona State University, 1996.

Marcoes, Lies et al. Kesaksian Para Pengabdi: Kajian tentang Perempuan dan Fundamentalisme di Indonesia. Jakarta: Rumah Kitab in cooperation with Norwegian Centre for Human Rights, 2014. 
Markas Besar Tentara Nasional Indonesia Pusat Pengkajian Strategis. Menghidupkan Kembali Kekhalifahan di Nusantara: Hizbut Tabrir Indonesia (HTI), Strategi Mobilisasi dan dampaknya Bagi Indonesia. Jakarta: Mabes TNI, 2010.

Muhtadi, Burhanuddin. "The Quest for Hizbut Tahrir in Indonesia," Asian Journal of Social Science, Vol. 37, No. 4, 2009.

Mulyono, GP and GP Mulyoto. "Radikalisme Agama di Indoensia (Ditinjau dari Sudut Pandang Sosiologi Kenegaraan)," Citizenship: Jurnal Pancasila dan Kewarganegaraan, Vol. 5, No. 1, 2017.

Nurjannah. "Faktor Pemicu Munculnya Radikalisme Islam Atas Nama Dakwah," Jurnal Dakwah: Media Komunikasi dan Dakwah, Vol. 14, No. 2, 2013.

Redaksi. "Strategi Perjuangan 'Khilafah' Pasca Pembubaran HTI, Waspadalah!," Suara Islam, at http://www.suaraislam.co/ strategi-perjuangan-khilafah-pasca-pembubaran-hti/ accessed on June 22, 2018.

Rodhi, Muhammad Muhsin. Tsaqofah dan Metode Hizbut Tabrir dalam Mendirikan Negara Khilafah. Bogor: Al Azhar, 2012.

Scott, James C. Domination and the Arts of Resistence: Hidden Transcipt. New Haven \& London: Yale University Press, 1990.

-----. Weapons of the Weak: Everyday Forms of Peasant Resistance. New Haven: Yale University, 1985.

Sinaga, Dames Alexander et al. "Gov't Officially Disbands Hizbut Tahrir Indonesia," Jakarta Globe (July 19, 2017), at https://jakartaglobe.id/context/govt-officially-disbandsHiz but-tahrir-indonesia accessed on February 16, 2021.

Taib, Sukrin Saleh. "Demokrasi Menurut Hizbut Tahrir Indonesia (Kajian tentang Konsep Pemikiran dan Gerakan Aktivis Hizbut Tahrir Indonesia Kota Gorontalo)." Ph.D Thesis-UIN Alauddin Makassar, 2013.

Triantini, Zusiana Elly and Masnun Tahir. "Terpasung tak Terasa (Melihat Eksistensi Politik Perempuan HTI)," UNISLA, Vol. 32, No. 71, 2009.

Umar, Ahmad Rizky Mardhatillah. "Melacak Akar Radikalisme Islam di Indonesia," Jurnal Ilmu Sosial dan Imu Politik, Vol. 14, No. 2, 2010. 
Wahid, Abdurrahman. "Musuh dalam Selimut," in Ilusi Negara Islam Ekspansi Gerakan Islam Transnasional di Indonesia. Jakarta: The Wahid Institute, 2009.

Wahid Foundation. "A Measure of The Extent of Socio-religious Intolerance and Radicalism within Muslim Society in Indonesia," National Survey Report, 2016.

----. "Akar Sejarah Gerakan Radikalisme di Indonesia," at http://wahidfoundation.org/index.php/news/detail/Akar-Sej arah-Gerakan-Radikalisme-di-Indonesia acces-sed on May 22, 2020.

Waluyo, Sapto. Kebangkitan Politik Dakwah. Bandung: Harakatuna Publishing, 2005.

Zuraya, Nidia. "Syekh Taqiyuddin al-Nabhani: Sang Pendidi Hizbut Tahrir," Republika, published on November 18, 2018 at republika.co.id.

\section{Interviews}

Afan (pseudonym). Gorontalo, October 19, 2018.

Dara (pseudonym). Gorontalo, October 17, 2018.

Laila. Gorontalo, October 18, 2018.

Lala (pseudonym). Gorontalo, October 19, 2018.

Syamsi. Gorontalo, November 18, 2018. 